\title{
ЈЕДНО ПИСМО КАО ИЗВОР ЗА ИСТОРИЈУ НОВОГ САДА У СРЕДЮЕМ ВЕКУ
}

\begin{abstract}
Апстракт: Збирка Подокатаро названа је по Лодовику Подокатару, личном лекару кардинала Родрига Борђије који је извесно време био и поседника Петроварадина (Новог Сада). Наиме, Борђија је своја најзначајнија документа држао депонована код Подокатара, тако и она која се односе на Петроварадин. Ову својеврсну збирку Подокатаро је депоновао у Венецији. После његове смрти збирка је постала власништво млетачке државе, која је извршила њену поделу. Значајнија документа за Серенисиму похрањена су у Млетачком архиву, а она друга уступљена су чувеној библиотеци Марћиана. Историчари Новог Сада до данас нису били свесни ове чињенице и наводили су током својих истраживања само један, или други део ове збирке. Коаторима овог саопштења, указала се у размаку од две деценије (1990-2012) прилика да на лицу места стекну увид у ову збирку и да констаутју како она, није у целини искоришћена, те овом приликом објављују једно писмо значајно за историју Петроварадина.
\end{abstract}

Кључне речи: Петроварадин, Петроварадинска опатија, Нови Сад, Збирка Подокатаро, Марћиана, Државни архив у Венецији

За италијанске архиве, у првом реду Ватикански и Млетачки може се рећи да представљају богат рудник за прошлост наших крајева.У овом раду осврнућемо се на Збирку Подокатаро која се чува у архиву у Венецији. Из те збирке издвајићемо само један податак који представља извор за историју Новог Сада односно Петроварадина.

Реч је о писму знаменитог великаша, принца, односно кнеза или војводе (у латинском језику за сва три наслова користи се реч: dux) Ловра Илочког састављеном 8. септембра 1490. године. У њему се аутор извињава папи Иноћентију VIII (1484-1492) због тога што је заузео Петроварадинску опатију. На основу наше транскрипције, која је резултат нашег коауторског истраживања у Венецији, писмо у латинском препису у целини гласи: 
На полеђини: Sanctissimo in Christo patri et domino, domino Innocentio, sacrosancte Romane, ac universalis ecclesie summo pontifici, domino meo clementissimo.

Beatissimo pater, domine mi clementissime! Post devotissimam mei commendationem, ad pedum oscula beatorum. Quanta fide observantia et devocione dive memorie Nicolaus rex Bosne, Genitor meus et ego Sanctam sedem Apostolicam semper coluerimus et Sanctitati Vestre predecessores ut veros Christi vicarios reveriti fuerimus plurima si necesse foret adduci testimonia possent. Ego vero qui parenti meo unicus heres successi quantum reverendam formidabilemque et obediencia dignissimam Apostolicam Sanctitatem Tuam cum clave regni coelorum collate sunt iudicaverim. Ex hoc facile elici potest, quod iniquium ab ullo uspiam vivente visus sum nec post hac unquam videbor aliud quam devotissimam semper reverenciam et obedienciam Sacrosancte Sedi apostolice et Sanctitati Tue impendisse. Conatus quippe totis viribus et conabor Sanctitati Tue me devotissimum et observantissimum filium in omnibus exhibere. Verum de gravamina meo quo vehementer augor mandato Sanctitatis Vestre monitorium ob receptum in manus meas Abbaciam Petri Waradini ad pedes eiusdem Sanctitatis Vestre recucuseream necesse est, ut vestra Sanctitas dijudicet, utrum ego in hoc periculoso tempore dignus sim Apostolice nuncione percolli ob factum, quod si Sanctitas Vestra intelligere a fundamento dignabitur, credo non penam me propter hoc, sed pietatem et favorem iudicabit promereri. Ego quidem Abbaciam Petri Waradini, quam vivente condam Rege Matthia, Reverendissimus dominus Petrus Archiepiscopus Colocensis ex Elleccione Regia et collacione Sanctissimi memorie Sixti pontificis Vestre predecessoris et hoc utraque legitima obtinuerat. Defuncto prefato Rege cum viderem per illum qui nomine Reverendissimi domini vicecancellarii illam occupatam tenebat, manus hostiles in arcem illius intromissas et plurima illinc qqui illi Abbatie vicinus patronusque sum merito michi et huic Regno formidanda committi expulsis inde emulorum meorum manibus non inficior in manus meas recipisse. Suadentibus eciam ymmo cogentibus pluribus dominis et primoribus Regni, quibus propter vicinam Turcorum et intestinas sediciones periculum illius Castri formidabile videbatur, postquam vero Sanctitatis Vestre clementia prefatus Archiepiscopus libertati restitutus est quanta ab his ipsis qui sibi captivitatem fabricaverant perpessus est et usquammodo paciatur cum res notissima sit malo aliis pocius narantibus quam me referente Sanctitas Vestra intelligat eius boni patri calamitati et affliccioni super estimacionem gravissime compassus quia Bude constitutus nec manere illic nec egredi audebat. Cum de voluntate Illustrissimi domini Johannis Corvini ducis etc. Paternitatem suam in Castra recepissem mea, cum meis confederatis communam partivis (? MR-PR) ipse cum illo persequi et infamari cepti sumus. Que tandem persecutio ad confederatos meos devoluta est. Sed archiepiscopus potissimos et ego turbatores pacis, seminatores zizanie, sedicionem auctores et omnis mali fabricatores nominati vociferatique sumus parum quam defuit quin post premissum domini sue Archiepiscopum nos ipsi cum castris profligati vitam amitteremus, post ea vero 
illi qui Archiepiscopo omne malum machinati a principio fuerant quique affliccionis illius tempore ut afflicto affliccionem adderent Reverendissimum dominum Vicecancellarium ad impetrandum sibi illius boni patris Abbaciam ex odio et invidia illius sollicitaverant, non destiterunt et hic Regnicolas et in Curia Romana Reverendissimus dominum Vicecancellarium incitare ut censuras contra michi in hac parte fautores pretextu ipsius Abbacie apportarentur. Quas certe tanti facto ut non pro Abbacia Petri Waradini sed nec pro Regno mundi vellem illas tolerare nisi evidens michi in hoc periculum a perte prospiciam evenire Illi cuius qui meum et ipsius domini Archiepiscopi periculum querunt, hoc pretextu quod Reverendissimo domino Vicecancellerio favent id agunt ut sub hoc colore de manu mea Arcem Abbacie extrahant et confestim tamquam pro tutela ipsius manus nobis hostiles intromittant. Quod si fieret Sanctitas vestra consideret me unacum ipso Archiepiscopo in apertum mittere periculum et quasi collo ligatum in carnificuam dedere non enim veris redditibus Abbacie arx illa hoc tempore sustentari posset. Et quo maiorem nobis emuli nostri inferrent perniciem vastacionem bonorum nostrorum necesse foret illam contra nos conservari, quam et nosnon pro utilitate nostra, sed pro quiete et tutela pocius communium non sine gravissimis et onerissimis expensis vigente necessitate maxima conservamus Nam aliter neque ego neque Archiepiscopus possemus amplius in hiis terris demorari. Sed alterum necesse foret, vel auffugere, vel perire. Quod ne fiat ardo eum sanctitatem vestram meam, vel ipsius Archiepiscopi, velcuiuspiam alterius Christiani evidentissimam non optare perniciem. Sed tamquam verum Christi vicarium, qui mortem peccatoris non querit, omnium suarum pocius salutem queretur, prostrates ante pedes vestr Sanctitatis supplico dignetur de pietate Apostolica, michi Sanctitatis vestre obedientissimo filio des absolucionis beneficio providere et vel iura ipsius archiepiscopi sola videre, vel mandare cui voluit revideri et si compertum fuerit ipsum unque et preter omnem iusticiam sub tanta et tam attroci affliccione sua odio et invidia emulorum abbacia spoliatum dignetur mandare illi pocius restitui illi cuius est quam illi qui viventis et in affliccioni positi hominis beneficium suggestione emula conatus est obtinere. In hoc Sanctitas vestra mi sibi obsequentissimum filium et servitorem ad omnia obsequia obligabit et illum bonum partem ab inimicorum persecucione liberabit et afflictam ultram quam vastitati subiectam Colocensis ecclesiam paterna pietate relevabit. Quam omnipotens deus conservet ad felix regimen Ecclesie sue Sacrosancte. Datum in Castro meo Wylak, octauo die Mensis Septembris. Anno domini Millesimo quadringentesimo Nonagesimo.

V(estre) Sanctitatis deuotissimus et obedientissimus filius et Seruitor

Laurentius dux etc. de Wylak 
Ово писмо познато је у историјској науци од раније. У српској језичкој средини на садржај овог документа указао је Роберт Пауловић, петроварадински адвокат и истраживач прошлости овог места. Он је свој прилог посвећен овој теми објавио још далеке 1954. године у Зборнику Матице српске за друштвене науке (Пауловић 1954: 128-132).

Пауловић је као место чувања оригинала писма Ловра Илочког означио Библиотеку светог Марка у Венецији, широм света познату под називом Марћиана (Marciana). Начин на који Пауловић то наводи ствара утисак, као да је он у наведеној установи у оригиналу користио тај докуменат, јер уколико није тако, он је био дужан да обележи посредством којих је међуинстанци дошао до њега (Станојев 2002: 165-166; Пауловић 1954: 128-132). Није нам познато, а не би вредело трагати за тим, да ли је Роберт Пауловић уистину лично истраживао у библиотеци Марћиани или не. Напротив, било је врло лако са сигурношћу утврдити, како се он, посредно, или непосредно служио делима других аутора, само што их није навео, (као што то чине и неки данашњи писци, боље речено преписивачи). Реч је о радовима мађарског историчара Вилмоша Фракноија, а посебно о његовој студији о животу калочко-бачког надбискупа Петра Варадија, иначе поседника Петроварадина. Фракнои у другој белешци свог рада на 736. страни каже, како се писмо налази „у венецијанској билиотеци” (Fraknói 1883: 734-749, 825). Из ове студије Пауловић је преписао, ако не читаве пасусе, барем целе реченице. Тадашње недовољно стручно уредништво Зборника за историју Матице српске за друштвене науке то изгледа није уочило.

Најевидентнија би била претпоставка, да је податак о налазишту наведеног писма Ловра Илочког, Пауловић, међу осталим подацима такође непосредно преузео од Фракноија. Није међутим искључена ни могућност да је то учинио путем неког текста Мелхиора (Мењхерта) Ердујхељија, монографа Новог Сада. Његово дело, иако застарело, у недостатку бољег и дан данас представља једини извор познавања целокупне прошлости овог града до пред крај XIX века, како за научну јавност, тако и за ширу читалачку публику. Оно је било објављено на три језика и то на: мађарском, српском и немачком. Из тог разлога, као што је добро познато, приређено је ново фототипско издање, на два од три језика на којима је оригинал писан, наиме на српском и мађарском. Ердујхељи се у својим делима, као што се види из његовог коректног научног апарата, уистину служио Фракноијевим подацима, па је могуће, да је Пауловић до својих сазнања дошао тим посредним путем (Ердујхељи 2002: 54, 56, 82-83; Érdujhelyi 1894: 61-65; Érdujhelyi 1899: 85-92).

Било, како било, Фракнои је уистину користио поменути докуменат, али je већ он погрешно навео место његовог чувања. Наиме, наведеног писма у библиотеци Марћиана ни у ком случају нема! Фракноијава грешка по свој вероватноћи потиче отуда, што ни он није видео оригинално писмо Ловра Илочког, него га је и он користио из друге руке, тј. у препису. 
Преписе млетачких докумената који се односе на историју Угарске, за Фракноија, односно Мађарску научну академију, чији је члан био Фракнои, правио је седамдесетих и осамдесетих година XIX века мађарски политички емигрант Јанош Мирче Баратоши, који је живео у Венецији и био службеник тамошњег архива. Мирче је посебну пажњу посветио повељама из једне збирке, која се зове Колекција Подокатаро (Tiepolo et all. 1991: 84, нап. 7).

Збирка Подокатаро (Collezzione Podocataro) названа је по Лодовику Подокатару (Lodovico Podocataro), Грку са Кипра, секретару и личном лекару кардинала Родрига Борђије (Rodrigo Borgia), потоњег папе Александра VI (1492-1503), који је неко време био поседник властелинства Петроварадина (данашњег Новог Сада). Као особи од највећег поверења, Александар VI је своја најзначајнија документа и она која се односе на Петроварадин (Нови Сад), држао депоноване код Подокатара. После смрти папе Александра VI, Лодовико Подокатаро је своју збирку 25. августа 1504. године завештао свом синовцу (nepos) Ливију, архиепископу Никозије.

Ливио Подокатаро, поставши грађанином Млетачке републике прешао је из Рима за Венецију. Он је са собом понео своју збирку докумената, међу њима и она која се односе на Петроварадин. После смрти Ливија Подокатара она су доспела у посед млетачке државе (Orazi 1952: 1644-1645). На тај начин ова документа су дошла, уместо у Ватикански архив у надлежност млетачких власти. Оне су извршиле селекцију и поделу збирке. Из политичког аспекта Републике, значајнија документа похрањена су у Млетачком архиву (Archivio di Stato, Venezia), а она друга уступљена су чувеној библиотеци Марћиана (Biblioteca Marciana) (Pélissier 1901: 473-493, 521- 576; Babinger 1960: 28-29, нап. 2).

За историчаре Новог Сада је значајно, како се та подела провлачи и кроз део грађе, која се односи на његову прошлост. Историчари овог града дуго нису били свесни ове чињенице и користили су током својих истраживања само један, или други део ове збирке. Коаторима овог саопштења, указала се у размаку од више од две деценије (1990-2012) прилика да на лицу места стекну увид у ову збирку и да констатују како она, без обзира на ранија истраживања још није у целини искоришћена, те приликом писања одавно планиране монографије Новог Сада требало би ту чињеницу узети у обзир и збирку Подокатаро темељно проучити.

Писмо Ловре Илочког припало је приликом поделе збирке Подокатаро, Државном архиву у Венецији. То потврђује печат на његовој полеђини. Она се налази тамо и данас, регистровано под сигнатуром бр. 6629, унутар ове збирке (Collezione Podocataro, b. 8. n. 617). Под овом сигнатуром писмо је нашао, приликом свог истраживачког боравка у Венецији у октобру 1990. године један од коаутора овог саопштења. Њему је пажњу на ову збирку скренуо покојни професор, академик Сима Ћирковић.

Поставља се питање како да се објасни грешка настала у навођењу овог писма код Фракноија. Њу треба тражити у околности, што су преписи Јано- 
ша Мирчеа, прављени са докумената из збирке Подокатаро, чуване у у библиотеци Марћиана и Државном архиву у Венецији, могли су се измешати било у рукописном одељењу Мађарске академије, или пак у рукама Фракноија, поготово ако Мирче није тачно обележио место њиховог чувања (MTAKK MS, 4978). Препис који се чува у рукописном одељењу Мађарске академије, у најновије време користио је Тамаш Феделеш у свом чланку о казненом походу против Ловре Илочког (Fedeles 2010: 284-286).

Да је уистину Мирче правио препис са оригинала, показује његова сигнатура: слова „М/С“, исписана бледо црвеном бојом на полеђини повеље. Мирче је наиме имао обичај да на оригиналима преписаних повеља напише „Mircse lemásolta“ на мађарском, или „Mircse copiavit“" на латинском језику (Collezione Podocataro, b. 8. n. 617). Наведена слова представљају свакако иницијале, односно скраћеницу његове белешке на латинском језику (Tiepolo et all. 1991: 84, напомена 7).

Коначно, пошто имамо снимак оригинала писма Ловре Илочког папи Иноћентију VIII, у могућности смо да извршимо неке исправке у његовом датирању, у чему су (Мирче?!) Фракнои и Пауловић такође погрешили. Они су наиме погрешили у датуму дана, наводећи да је ово писмо писано 7. септембра (Fraknói 1883: 736, нап. 2; Пауловић 1954: 99). У тексту међутим јасно и читљиво стоји: „,оctauo die mensis Septembris“ (подвукли аутори), тј. осмог дана месеца септембра (Podocataro, b. 8. n. 617). У претходној напомени Фракнои додуше исправно датира писмо за 8. септембар, али не наводи место у којем је настало, тако да се не види да је реч о истом писму (Fraknói 1883: 736, нап. 1). Поред тога, Роберт Пауловић је такође погрешио у години настанка писма, стављајући га у 1491 (Пауловић 1954: 99). У оригиналном тексту се пак добро види да је писмо Ловре Илочког папи Иноћентију VIII настало годину дана раније, односно 1490 (Podocataro, b. 8. n. 617).

Тек пошто смо овако исправили Пауловићеву грешку, има донекле смисла његова констатација, по којој се, истовремено са Ловром Илочким, по питању петроварадинске опатије, папи Иноћентију VIII обратио и калочко-бачки надбискуп Петар Варади. Кажемо донекле, јер је он то учинио дан раније, тј. 7. септембра 1490. године. Писмо Петра Варадија, као што је то Пауловић тачно навео, чува се уистину у Библиотеци Светог Марка у Венецији, куда је доспело након поделе Збирке. Коначно, Роберт Пауловић погрешио је још једанпут, идентификујући у писму поменутог папу Сикста, са Сикстом III (Пауловић 1954; 100, 111, нап. 21). Ради се, разуме се, о савременику ових личности; четвртом папи са овим именом, који је владао од 10. августа 1471. до 12. августа 1484. године (Grotefend 2006: 133; Szentpétery 1912: 35; Pastor 1925: 451-710).

Са наведеним писмима Петра Варадија и Ловре Илочког, започела је позната борба за поседовање петроварадинске опатије и тврђаве. Што се историографије тиче, ток овог сукоба познат је у својим главним цртама. Обиловала је заплетима и завршио се након шест година (1496), победом 
калочко-бачког надбискупа, Петра Варадија. Што се пак Ловра Илочког тиче, који је заузео петроварадинску опатију под изговором да штити интересе надбискупа Петра, предао ју је 1492. године кардиналу Родригу Борђији. Пошто је овај исте године под именом Александар VI постао папа, вратио ју је уз велики откуп, 1496. године Петру Варадију. Роберт Пауловић је, очигледно, на основу радова Вилмоша Фракноија и Мелхиора Ердујхељија, такође писао о овим историјским догађајима, доводећи међутим, читаоце на погрешну мисао да се приликом свог рада служио оригиналним изворима, међу којима се налазило и писмо Ловра Илочког папи Иноћентију VIII. Коначно, Пауловић није ни занао где се овај документ тачно налази (Fraknói 1883: 734-749; Ердујхељи 1894: 52, 56, 82-83; Érdujhelyi 1894: 73-76; Пауловић 1954: 128-132).

Та борба се, да закључимо, одвијала у виду интензивне кореспонденције. Канцеларије ова три угледника европске историје током шест година издале су хрпу писама, од којих се већина и данас уистину чува у Библиотеци светог Марка (Марћиани) (Pélissier 1901: 483; Babinger 1960: 28-29; нап. 2). Писмо Ловра Илочког папи Иноћентију VIII од 8. септембра 1490. године, међутим, представља изузетак. Да поновимо, оно се налази у Државном архиву у Венецији (Podocataro, b. 8. n. 617).

Као методолошки закључак овог рада можемо препоручити да се извори уопште, па и они за монографију Новог Сада, по могућности користе у оригиналу. Дигитализација грађе релевантних архива у најновије време, уз одговарајуће стручно знање то омогућава истраживачима. Наравно, зато је потребно стручно знање, које се може стећи само на стручним студијама из уже научне области медијевистике. Са намером да им то са наше стране олакшамо, у овом раду саопштили смо текст писма Ловра Илочког, папи Иноћентију VIII, од 8. септембра 1490. године, у оригиналном аутографу.

\section{ИЗВОРИ И ЛИТЕРАТУРА}

Babinger, Franz (1960). Das Ende der Arianiten. Sitzungsberichte der Bayerische Akademie der Wissenschaften, Phil.-hist. Klasse, Hft. 4.

Grotefend, Herman (2006). Računanje vremena u nemačkom srednjem i novom veku. (prevod devetog izdanja), ed. Atila Hornok. Novi Sad: Stylos.

Ердујхељи, Мелхиор (2002). Исӣорија Нової Саgа. Нови Сад 1894 репринт. Ветерник: Дијам-М-прес

Érdujhelyi, Menyhért (1899). Kalocsai érsekség Érdujhelyi Menyhért, A kalocsai érsekség a renaissance korban. Zenta.

Érdujhelyi, Menyhért (1894). Ujvidék története. Ujvidék.

A Magyar Tudományos Akadémia Történelmi bizottságának oklevélmásolatai. A Magyar Tudományos Akadémia irattára (=MTAKK, Ms). (Velencei másolatok, 3. doboz).

Orazi, Ansenda R. (1952). Podocataro Lodovico. Enciclopedia Cattolica, IX, Oa-Pre, Citta del Vaticano. 
Pastor, Ludwig (1925). Geschichte der Päpste, II, Von der Thronbesteigung Pius II, bis zum Tode Sixtus IV, 1458-1484. Freiburg im Breisgau: Herder

Pélissier, Léon G. (1901). Catalogue des documents de la collection Podocataro a la Biblioteca Marciana a Venise. Centralblatt für Bibliothekswesen, 18, 473-493 521- 576.

Пауловић, Роберт (1954). Борба калочкой наgбискуйа Пейра Вараgија за йейровараgинску йврђаву. Зборник Матице српске, Серија друштвених наука, 6: 128-132.

Szentpétery, Imre (1912). Oklevéltani naptár. Budapest: A Magyar Tudományos Akadémia

Стан(ојев), Б(огдан) (2002). Пауловић Роберӣ. Енциклопедија Новог Сада, 19, Пад - Пет, Нови Сад: Новосадски клуб: 165-166.

Tiepolo, Maria Francesca - Migliardi O’Riordan, Giustiniana - Scarpa, Piero -Baroni, Manuela - Centre international d'information sur les sources de l'histoire balkanique et méditerranéenne (1991). Esempi di scritture dei secoli XII-XVIII. [Roma] : Ministero per i Beni culturali e ambientali; Venezia : Archivio di Stato di Venezia.

Fedeles, Tamás (2010). Az 1494-1495-ös királyi büntetö hadjárat elözményei. In: Font MártaFedeles Tamás-Kiss Gergely, Aktualitások a magyar középkorkutatásban, Pécs: PTE-BTK: 277-291.

Fraknói Vilmos (1883).Váradi Péter kalocsai érsek élete, 1480-1501. Századok, XVII: 729749, 825-843.

Collezione Podocataro, Archivio di Stato Venezia.

Petar Rokai - Melina Rokai

\section{ONE LETTER AS SOURCE FOR MEDIEVAL HISTORY OF NOVI SAD}

\section{SUMMARY}

Collection Podocataro was named after Ludovico Podocataru, personal doctor of Rodrigo Borgia, who was also for a while the possessor of Petrovaradin (Novi Sad). He kept his most important documents deposited with Podocataro, thus also those relating to Petrovaradin. Podocataro transferred them to Venice. After his death, they came into the ownership of the Venetian state, which carried out the division of the collection. Documents more important from the political aspect were stored in the Venetian archives, whereas the latter were ceded to the famous Bibliotheca Marciana. Until these days, historians of Novi Sad were not aware of this fact and during their research stated the one or the other part of this collection. In a span of two decades (1990-2012), co-authors of this paper, had an opportunity to gain on-site access to this collection and state that it has not been fully utilized, and thus this time here they publish a letter significant for the history of Petrovaradin.

Key words: Petrovaradin, Novi Sad, Collection Podocataro, Marciana, Арцхивиоди стато Венезиа. 